\section{Fra top til tå \\ - billeder fra en fotoautomat}

af mag.art. Birna Marianne Kleivan

$\mathrm{E}$ nhver, der har vovet sig ind $i$ en fotoautomat, kender følelsen. Man lægger ansigtet i fordelagtige folder og poserer efter bedste evne. Alligevel står anstrengelserne sjældent mål med resultatet, når billederne få minutter senere dumper ud af maskinen. Som portrætter betragtet er fotografierne ikke bare sært anonyme. Ofte oplever man tillige at se sig forvandlet til en mere eller mindre terroristlignende personage.

Ikke desto mindre produceres der mere end en halv million billeder årligt i danske fotoautomater, ligesom denne type fotografi har en enorm udbredelse globalt set.

De fleste automatoptagelser finder anvendelse i pas og andre former for ID-kort. Som sådan besidder de en betydelig autoritet, idet disse på mange måder så intetsigende billeder danner grundlag for personidentifikation. $\mathrm{Og}$ det til trods for at den afbildede kan have svært ved om ikke at genkende sig selv, så dog nødigt vil kendes ved sit eget kontrafej.

Mindre kendt er den utraditionelle brug af fotoautomaten. Således er maskinens lille kabine også hjemsted for utallige klovnerier samt mere pikante udfoldelser i dagligdagen, ligesom Andy Warhol blot er en af de mange kendte billedkunstnere, der har benyttet auto- maten som et kreativt udtryksmiddel.

Fotoautomatens popularitet skyldes ikke blot, at den leverer hurtige billeder til en billig penge. Nok så væsentlig er det faktum, at der er tale om en fotografløs billeddannelse. Hertil kommer automatens karakter af et privat rum midt i det offentlige ditto, hvilket indirekte indbyder til 'forbudte' handlinger. Noget især yngre automatkunder synes at have stor fornøjelse af.

Blandt Kort- og Billedafdelingens henved 11 millioner enheder er det hidtil kun lykkedes undertegnede at lokalisere én enkelt automatstrimmel. Så meget desto mere interessant er det, at den pågxldende billedserie både rummer et typisk automatportræt og samtidig bryder med de udstukne regler for gængs automatposering. Resultatet er pudsigt og overraskende vellykket.

For reportagefotografen Henrik Saxgren, hvem billederne viser, har den lille fotostrimmel en særlig betydning, idet den kuriøst nok repræsenterer hans første salg til en offentlig samling. At den prisbelønnede fotograf siden har udført en række opsigtsvækkende portrætter af kendte danskere til Frederiksborgmuseets permanente samling, er en anden historie.

Automatstrimlen udgjorde Saxgrens bidrag til den store udstilling Fotografer ser sig selv - 73 seluportratter, som blev indkøbt af Det Kongelige Bibliotek efter visningen i Rundetårn i forsommeren 1989. Udstillingen markerede 150 -året for fotografiets officielle fødsel og var arrangeret af museumsinspektør Tove Thage i samarbejde med fotografen Suste Bonnen. Når de i jubi- 
læumsåret havde valgt at fokusere på netop selvportrættet, skyldtes det med Tove Thages ord, "at denne dialog mellem fotografen og mediet viser noget centralt om fotografiet som kunstnerisk udtryksmiddel."

I det ledsagende katalog lagde de to arrangører imidlertid ikke skjul på, at det havde krævet store overtalelsesevner at få deltagerne til at vende kameraet mod sig selv. Formodentlig fordi danske fotografer, i modsætning til mange af deres udenlandske kollegaer, ikke har tradition for at dyrke selvportrættet i synderlig grad.

$\mathrm{E}$ $\mathrm{n}$ af de mest skeptiske fotografer var Henrik Saxgren, som i første omgang afslog at medvirke i udstillingen.

"Det er sjældent særlig interessant, når fotografer piller navle. Derimod synes jeg det er interessant, når fotografer stiller sig til rådighed som medie og udsætter sig for alskens strabadser i skildringen af fx. subkulturer eller kriseområder. Via deres interesse for andre mennesker går fotograferne samtidig på opdagelse i sig selv. Men billederne er ofte langt mere vedkommende end de rendyrkede selvportrætter," hævder Henrik Saxgren, hvis mangeårige virke som bl.a. socialpolitisk dokumentarfotograf ikke fornægter sig, når han idag skal forklare sin udtalte modvilje overfor udstillingskonceptet.

Ikke desto mindre var Saxgren at finde blandt deltagerne i den store selvportrætvisning. Efter eget udsagn fordi han ønskede at gøre sin holdning kendt, idet hans automatbidrag demon- strativt skulle signaliserede det minimum af tid, han havde investeret i projektet.

Selve fotoserien består af ialt fire billeder. Det første viser en anspændt, lettere overrasket Henrik Saxgren, der med vagtsomme øjne stirrer ind $\mathrm{i}$ kameraet. I de to efterfølgende billeder ses henholdsvis hans påklædte overkrop og mellemgulv, mens fotografens ene hånd og ben, herunder hans løftede højre fod, præsenteres i det fjerde og sidste billede.

Saxgren har med andre ord valgt at trodse fotoautomatens udstukne retningslinjer, der udelukkende sigter mod ansigtsforevigelse. I stedet udforsker han på original vis de formmæssige rammer, idet han med sine forskudte kropsstudier tilstræber at skabe et i dobbelt forstand udvendigt billede af sig selv $i$ hel figur.

Stor portrætkunst er der ikke tale om, men serien er ikke desto mindre et udsagn af og om fotografen Henrik Saxgren, og kan som sådan betragtes som et selvportræt. Ikke mindst hvis man tilslutter sig tesen om at ethvert billede tillige er et portræt af dets ophavsmand.

S om helhed betragtet illustrerede udstillingen Fotografer ser sig selv 73 selvportratter, hvor krævende en genre selvportrættet er for personer, der $\mathrm{i}$ det daglige foretrækker at befinde sig bag kameraet. Det skortede ikke på kreative tiltag, men havde man samtidig forventet en række nærgående personstudier, var mange af fotograferne påfaldende skjulte. 


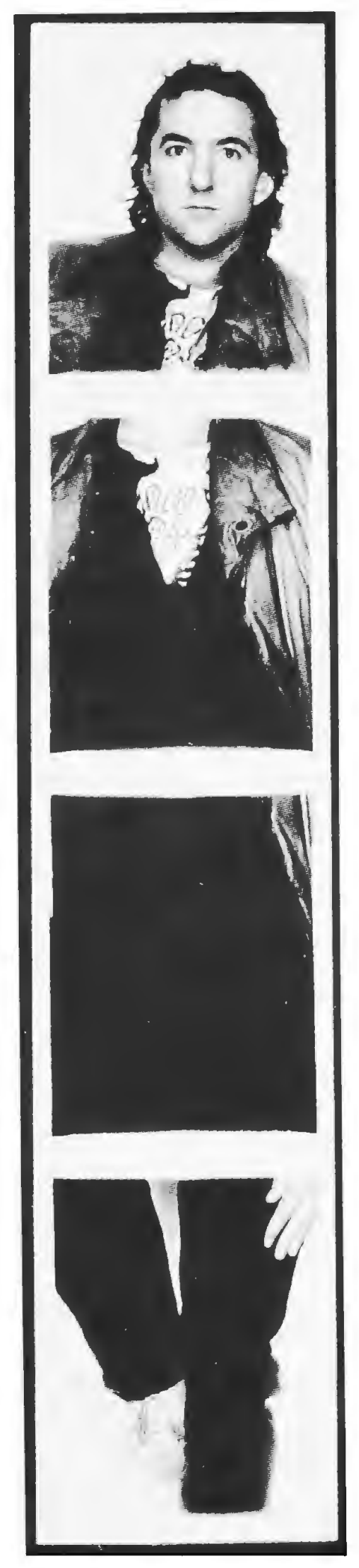

Henrik Saxgren i fotoautomaten 1989. (Originalen er ifarve)
Ganske vist bød udstillingen på psykologiserende selvfremstillinger, men det var de mere udvendige såkaldte idéportrætter, der syntes at dominere. Således var hittepåsomheden stor $i$ mange af bidragene, ligesom det at optræde afklædt ingenlunde var garant for et i overført forstand nøgent selvportræt, idet skildringerne ofte koncentrerede sig mere om selve ideen, herunder masken, end personen bag.

Hvorfor Saxgrens automatstrimmel blev forbigået i samtlige dagbladsanmeldelser, kan man kun gisne om. Men sikkert er det, at den anerkendte fotografs valg af medie alene medvirkede til at mange ikke tog hans bidrag seriøst.

Siden opfindelsen i $1890^{\prime}$ erne har den prisbillige fotoautomat været behæftet med særdeles lav status i offentlighedens øjne, ligesom automatens eksistens generelt forbigås i fotohistoriske oversigtsværker. Formodentlig ud fra en opfattelse af, at der blot er tale om en maskine, hvis standardiserede produkt intet har med kunstnerisk skaben at gøre.

Myndighedernes tillid til automatportrættet synes f.eks. netop at have forbindelse til ovennæunte forhold. Det er da heller ikke tilfældigt, at automatfotografiet omtales som et 'forbryderbillede' i folkemunde, idet politiets identifikationsfotos af mistænkte og kriminelle stilistisk danner prototypen for pasog ID-fotografiet.

Følelsen af at ligne en terrorist på sit pasbillede udspringer netop af dette faktum. Hertil kommer den anspændthed, som præger de respektive af- 
bildningssituationer, hvilket også forklarer hvorfor Saxgrens automatportræt vækker påminder om en jaget desperado. Med sin kreative indfaldsvinkel udfordrer Saxgren den gængse opfattelse af fotoautomaten, for samtidig bevidst at spille på såvel statusforhold som automat-billedets traditionelle anvendelse. Hermed bliver hans udstillingsbidrag et polemisk udsagn omkring selvportrætgenren og identitetsbegrebet som sådan.
At billedserien tillige kan tolkes som udtryk for hans selvopfattelse, medgiver Saxgren gerne; "Set i bakspejlet tror jeg min automatstrimmel var et forsøg på at sige: Jeg bruger ikke tid på mig selv, ergo er jeg ikke selvoptaget ligesom de andre. Det er da også et signal ... Som måske i virkeligheden handler om, at man er enormt selvoptaget," tilføjer Henrik Saxgren med et skævt smil.

Birna Marianne Kleivan forsker i fotoautomatens historie og udgiver til næste år bogen, Fotografiet uden fotograf - automatbilleder gennem $100 \mathrm{ar}$. 